\title{
Isolasi dan Identifikasi Bakteri Pelarut Fosfat dari Tanah Gambut
}

\author{
Ella Dewani Larasati, MG Isworo Rukmi, Endang Kusdiyantini dan R Cinta Badia Ginting \\ Departemen Biologi, Fakultas Sains dan Matematika, Universitas Diponegoro \\ Jl. Prof Soedharto, SH, Tembalang, Semarang 50275 \\ larasdewani@yahoo.co.id
}

\begin{abstract}
Phosphate $(\mathrm{P})$ are macronutrients that necessary for growth and development of plants, But the availability of phosphate dissolved in the ground are very limited because trend is bound to minerals ground form phosphate complexs. One of the alternative to improve the efficiency of phosphate is by utilize phosphate solubilizing bacteria. Phosphate solubilizing bacteria is bacteria capable of dissolving phosphate that is not available become available, so that it can be absorbed by plants. Peat soils can be used as a source of phosphate solubilizing bacteria because, peat soils formed from litter and organic matter so, many microorganisms which live in peat soils one of them is a phosphate solubilizing bacteria. The aim of this research is to isolat, identify bacteria to species level using Biolog system GenIII Mircoplate, and test the ability of phosphate dissolution. The isolation is done with the methods spread plate in a media pikovkaya solid and testing the ability to isolat qualitatively glimpsed clear zone around colonies, measuring phosphate solubilizing index. testing the ability isolats quantitatively by measuring solubility phosphate using spektrofotometer, and identification isolats using Biolog System. Eighteen isolates phosphate solubilizing bacteria successfully obtained from of peat soils, two isolates of them potential in solubilizing phosphate, According to Biolog system the second isolates identified as Pseudomonas tolaasii (isolate PG2T.5) and a Bacillus pumilus (isolate PG3TT.2), each is about phosphate dissolved successive of $24,81 \mathrm{mg} / \mathrm{L}$ and $22,62 \mathrm{mg} / \mathrm{L}$
\end{abstract}

Key words: Peat Soil, Isolation, Phosphate Solubilizing Bacteria, Biolog System Identification

\begin{abstract}
Abstrak
Fosfat $(\mathrm{P})$ merupakan salah satu unsur hara makro yang sangat penting bagi pertumbuhan dan perkembangan tanaman, namun ketersediaan fosfat terlarut di dalam tanah sangat terbatas karena kecenderungannya terikat dengan mineral tanah membentuk fosfat kompleks. Salah satu alternatif untuk meningkatkan efisiensi penggunaan fosfat adalah dengan memanfaatkan bakteri pelarut fosfat. Bakteri pelarut fosfat merupakan bakteri yang mampu melarutkan fosfat yang tidak tersedia menjadi tersedia sehingga dapat diserap oleh tanaman. Tanah gambut dapat digunakan sebagai sumber bakteri pelarut fosfat karena, tanah gambut terbentuk dari serasah dan bahan organik sehingga, banyak mikroorganisme yang hidup di tanah gambut salah satunya adalah bakteri pelarut fosfat. Penelitian ini bertujuan untuk mengisolasi, mengidentifikasi bakteri sampai tingkat spesies menggunakan Sistem Biolog GenIII Microplate, dan menguji kemampuan pelarutan fosfat. Isolasi dilakukan dengan metode spread plate pada media Pikovkaya padat, aktivitas pelarutan fosfat diuji secara kualitatif dengan melihat munculnya zona bening di sekitar koloni dan mengukur indeks pelarutan fosfat, uji kemampuan isolat secara kuantitatif dengan mengukur kelarutan fosfat menggunakan spektrofotometer, dan identifikasi isolat menggunakan sistem Biolog. Delapan belas isolat bakteri pelarut fosfat berhasil diperoleh dari tanah gambut, dua isolat diantaranya potensial dalam melarutkan fosfat, menurut sistem Biolog kedua isolat tersebut teridentifikasi sebagai Pseudomonas tolaasii (Isolat PG2T.5) dan Bacillus pumilus (Isolat PG3TT.2), masing-masing memiliki kadar fosfat terlarut berturut-turut sebesar $24,81 \mathrm{mg} / \mathrm{L}$ dan $22,62 \mathrm{mg} / \mathrm{L}$
\end{abstract}

Kata Kunci: Tanah Gambut, Isolasi, Bakteri Pelrut Fosfat, Identifikasi Sistem Biolog

\section{PENDAHULUAN}

Fosfor $(\mathrm{P})$ merupakan unsur hara esensial makro seperti halnya karbon $(\mathrm{C})$, dan nitrogen $(\mathrm{N})$. Tanaman memperoleh unsur $\mathrm{P}$ seluruhnya yang berasal dari tanah atau dari pembusukan serta hasil dekomposisi dan mineralisasi bahan organik. Jumlah P total dalam tanah cukup banyak, namun yang tersedia bagi tanaman jumlahnya rendah 
(Handayanto, 2007). Pemberian pupuk fosfor pada tanah seringkali menjadi tidak efisien, karena fosfor yang diberikan pada tanah akan berikatan dalam bentuk Al-P, Fe-P, dan Ca-P. Tanaman memanfaatkan fosfat hanya sebesar 10-30\% dari pupuk fosfat yang diberikan, berarti 70-90\% pupuk fosfat tetap berada di dalam tanah. Salah satu alternatif untuk meningkatkan efisiensi pemupukan fosfat, dalam mengatasi rendahnya fosfat tersedia dalam tanah adalah dengan memanfaatkan bakteri pelarut fosfat.

Bakteri pelarut fosfat adalah bakteri yang dapat melarutkan fosfat sukar larut menjadi larut, baik yang berasal dari dalam tanah maupun dari pupuk, sehingga dapat diserap oleh tanaman (Alfiah et al., 2016). Prinsip mekanisme pelarutan mineral fosfat adalah produksi asam-asam organik, dan enzim asam fosfatase yang berperan dalam mineralisasi fosfat organik pada tanah (Setiawati \& Pranoto, 2015).

Sistem Biolog merupakan alat untuk mengidentifikasi mikroba. Sistem Biolog dapat dengan cepat mengidentifikasi lebih dari 2,900 spesies bakteri anaerobic, aerobic, yeast, dan fungi. Perangkat Omnilog Gen III dapat menganalisis kemampuan sel untuk metabolisme semua kelas utama senyawa biokimia, selain menentukan sifat fisiologis penting lainnya seperti $\mathrm{pH}$, salinitas, toleransi asam laktat, kekuatan reduksi, dan sensitivitas terhadap senyawa kimia. Microplate pada sistem Biolog terdiri dari 96 uji yang secara bersamaan memberikan reaksi pola karakterisasi yang disebut "sidik jari metabolisme". Reaksi sidik jari ini memberikan sejumlah besar pola informasi yang terdapat pada satu microplate Biolog. Pola tersebut kemudian dibandingkan dengan database yang ada pada perangkat lunak Biolog, yaitu Microlog TM untuk tujuan identifikasi (Biolog, 2011).

Mengingat pentingnya bakteri pelarut fosfat untuk kesuburan tanah, maka isolasi dan skrining bakteri perlu dilakukan untuk mendapatkan spesies yang unggul. Penelitian ini bertujuan untuk menemukan bakteri pelarut fosfat dari tanah gambut, menguji kemampuan bakteri dalam melarutkan fosfat, dan mengidentifikasi bakteri sampai tingkat spesies menggunakan Biolog System GenIII Micropla.

\section{BAHAN DAN METODE Isolasi Bakteri Pelarut Fosfat dari Tanah Gambut}

Sampel tanah gambut (diambil dari daerah Kalimantan, Jambi, dan Palembang) sebanyak 10 gram dimasukkan ke dalam $90 \mathrm{ml}$ larutan garam fisiologis $0.85 \%$, kemudian diinkubasi menggunakan shaker selama 3 jam, pada suhu ruang dengan kecepatan agitasi $120 \mathrm{rpm}$. Bakteri diisolasi dengan metode spread plate pada media Pikovkaya padat (glukosa $10 \mathrm{~g}$; $\mathrm{Ca}_{3}\left(\mathrm{PO}_{4}\right)_{2} 5 \mathrm{~g}$; $\left(\mathrm{NH}_{4}\right)_{2} \mathrm{SO}_{4} 0,5 \mathrm{~g} ; \mathrm{NaCl} \mathrm{0,2} \mathrm{g} ; \mathrm{MgSO}_{4} .7 \mathrm{H}_{2} \mathrm{O} \mathrm{0,1} \mathrm{g}$; $\mathrm{KCl} \mathrm{0,2} \mathrm{g;} \mathrm{yeast} \mathrm{ekstrak} \mathrm{0,5} \mathrm{g;} \mathrm{MnSO}_{4} \cdot \mathrm{H}_{2} \mathrm{O} 0,002$ $\mathrm{g} ; \mathrm{FeSO}_{4} .7 \mathrm{H}_{2} \mathrm{O} 0,002 \mathrm{~g}$ ). Inkubasi dilakukan selama 2-3 hari pada suhu ruang. Pertumbuhan bakteri pelarut fosfat ditandai dengan adanya zona bening di sekeliling koloni. Koloni bakteri dipurifikasi kembali sampai didapatkan isolat murni.

\section{Pengujian Kemampuan Isolat sebagai Bakteri Pelarut Fosfat secara Kualitatif}

Kultur bakteri yang berumur 24 jam yang ditumbuhkan media NB diambil sebanyak $5 \mu \mathrm{l}$ diinokulasikan pada media Pikovskaya padat dan diinkubasi selama 7 hari pada suhu ruang. Zona bening yang terbentuk di diukur dan dihitung indeks pelarutan (IP) dengan rumus sebagai berikut (Paul \& Sinha, 2016).

$$
\mathrm{IP}=\frac{\text { Diameter } \text { Zona Bening }(\mathrm{mm})}{\text { Diameter koloni }(\mathrm{mm})}
$$

\section{Pengujian Kemampuan Isolat sebagai Bakteri Pelarut Fosfat secara Kuantitatif}

Isolat bakteri diinokulasi ke media pikovskaya cair dan diinkubasi selama 15 hari. Setelah 15 hari, kultur kemudian disaring dengan kertas whatman no.1 sampai mendapatkan didapatkan $20 \mathrm{ml}$ supernatan. Sebanyak $13 \mathrm{ml}$ filtrat dimasukkan ke dalam tabung sentrifuse dan disentrifugasi dengan kecepatan $1000 \mathrm{rpm}$ selama 15 menit. Supernatan hasil sentrifugasi dipipet sebanyak $5 \mathrm{ml}$ dan dipindahkan ke dalam tabung reaksi, pereaksi pewarna $\mathrm{P}$ pekat ditambahkan sebanyak 1ml KH2PO4 (0,295 g/100ml) digunakan untuk membuat larutan baku 1000 ppm, kemudian diencerkan untuk mendapatkan konsentrasi 0 ppm, 2 ppm, 4 ppm, 6 ppm, 8 ppm, 10 ppm. Larutan baku dan sampel yang telah ditambahkan pereaksi $\mathrm{P}$ 
pekat dan diinkubasi selama 30 menit, kemudian pelarutan fosfat diukur secara kuantitatif dengan menggunakan spektrofotometer UV VIS dengan panjang gelombang $693 \mathrm{~nm}$.

\section{Identifikasi Isolat Bakteri Pelarut Fosfat}

Identifikasi isolat bakteri pelarut fosfat dilakukan berdasarkan pengamatan makroskopik, mikroskopik, dan uji biokimia menggunakan sistem Biolog. Pengamatan mikroskopis dilakukan dengan mengamati bentuk, permukaan, tepi dan warna koloni. Pengamatan mikroskopis dilakukan dengan mengamati morfologi sel isolat bakteri yaitu bentuk sel, motilitas, dan panjang sel yang berumur 24 jam dan ditumbuhkan pada media NB. Pengamatan diamati di bawah mikroskop Olympus DP2-BSW dengan perbesaran 1000x.

Uji biokimia menggunakan Biolog model ELX808BLG serial 1306184 dengan Buffer IF-A. Kultur murni diremajakan pada media NA, diinkubasi selama 24 jam. Buffer IF-A diinokulasi dengan isolat bakteri menggunakan cotton bud (tampone swab) steril. Buffer yang sudah diinokulasi bakteri, kemudian diukur kepadatan selnya menggunakan turbidimeter sampai diperoleh percent transmittance menunjukkan angka 98 (absorbansi 0,2). Larutan buffer dimasukkan ke dalam wadah steril, kemudian diambil dengan menggunakan mikropipet dan dimasukkan ke dalam microplate 96 well masing-masing $100 \mu \mathrm{l}$. Sampel diinkubasi pada suhu ruang selama 16-24 jam, sampel kemudian dimasukkan ke dalam Biolog Microstation untuk dilakukan pembacaan berdasarkan karakter uji biokimia dari isolat bakteri yang diidentifikasi dan dicocokkan dengan database yang ada di komputer..

\section{HASIL DAN PEMBAHASAN Isolasi Bakteri Pelarut Fosfat dari Tanah Gambut}

Tanah gambut yang digunakan sebagai sumber isolat bakteri pelarut fosfat (BPF) diperoleh dari daerah Kalimantan, Jambi dan Palembang, berturut-turut sebanyak 4, 8, dan 11 sampel. Tabel 1. menunjukkan, bahwa pada sampel asal Kalimantan dan Jambi tidak ditemukan adanya bakteri pelarut fosfat, sedangkan pada sampel Palembang terdapat 18 isolat. Bakteri pelarutkan fosfat dikenali dengan adanya zona bening di sekitar koloni bila di tumbuhkan pada media agar Pikovskaya. Sagervansh et al. (2012) menyatakan bahwa, terbentuknya zona bening di sekitar koloni menunjukkan, bahwa isolat tersebut mampu menghasilkan asam-asam organik yang mampu berikatan dengan ion $\mathrm{Ca}^{-}$membentuk senyawa $\mathrm{Ca}_{3}\left(\mathrm{PO}_{4}\right)_{2}$ pada media agar Pikovskaya dan membebaskan ion $\mathrm{H}_{2} \mathrm{PO}_{4}^{-}$sehingga membentuk area yang berwarna lebih jernih.

Tabel 1. Hasil isolasi bakteri pelarut fosfat dari tanah gambut

\begin{tabular}{|c|c|c|c|}
\hline $\begin{array}{c}\text { Asal } \\
\text { sampel }\end{array}$ & $\begin{array}{c}\text { Kode } \\
\text { sampel }\end{array}$ & $\begin{array}{c}\text { Jumlah } \\
\text { Isolat }\end{array}$ & Kode Isolat \\
\hline \multirow[t]{4}{*}{ Kalimantan } & KG1 & 0 & - \\
\hline & KG2 & 0 & - \\
\hline & KG3 & 0 & - \\
\hline & KG4 & 0 & - \\
\hline Total & & 0 & \\
\hline \multirow[t]{8}{*}{ Jambi } & JG1 & 0 & - \\
\hline & JG2 & 0 & - \\
\hline & JG3 & 0 & - \\
\hline & JG6 & 0 & - \\
\hline & JG7 & 0 & - \\
\hline & JG8 & 0 & - \\
\hline & JG9 & 0 & - \\
\hline & JG10 & 0 & - \\
\hline Total & & 0 & \\
\hline \multirow[t]{8}{*}{ Palembang } & PGITT & 1 & PGITT.5 \\
\hline & PG3TT & 3 & PG3TT.1, PG3TT.2, PG3TT.3 \\
\hline & PG6TT & 7 & $\begin{array}{l}\text { PG6TT.1, PG6TT.3, PG6TT.4, } \\
\text { PG6TT.5, PG6TT.6, PG6TT.7, } \\
\text { PG6TT.8 }\end{array}$ \\
\hline & PG10TT & 2 & PG10TT.1,PG10TT.2 \\
\hline & PG2T & 1 & PG2T.5 \\
\hline & PG4T & 1 & PG4T.1 \\
\hline & PG5T & 2 & PG5T.3, PG5T.4 \\
\hline & PGK2T & 1 & PGK2T.2 \\
\hline Total & & 18 & \\
\hline
\end{tabular}

Hasil isolasi mendapatkan 18 isolat yang selanjutnya diuji kemampuannya secara kualitatif dalam melarutkan fosfat dengan mengukur indeks kelarutan fosfat berdasarkan zona bening yang terbentuk dan secara kuantitatif pada media Pikovskaya cair untuk megetahui seberapa besar kelarutan fosfat yang dihasilkan. 
Kemampuan Isolat Bakteri Pelarut Fosfat Secara Kualitatif

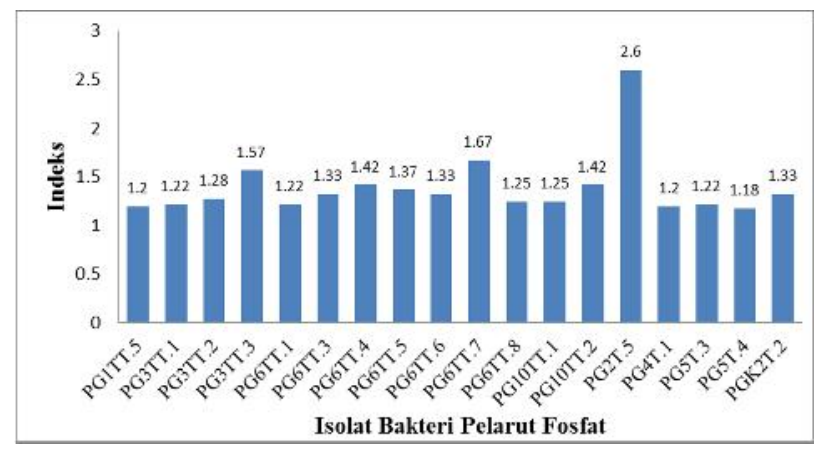

Gambar 1. Grafik indeks pelarutan fosfat pada bakteri pelarut fosfat.

Berdasarkan grafik indeks pelarutan fosfat pada bakteri pelarut fosfat di atas, dapat dilihat bahwa isolat PG2T.5 memiliki indeks kelarutan fosfat tertinggi, yiutu sebesar 2,6. Hal ini menunjukkan bahwa isolat tersebut memiliki aktivitas enzim fosfatase dan menghasilkan asamasam organik yang tinggi. Situmorang et al. (2015) menyatakan bahwa semakin tinggi aktivitas enzim yang dihasilkan bakteri pelarut fosfat, semakin besar zona bening yang dihasilkan. Zona bening terbentuk akibat terlarutnya fosfat tidak terlarut menjadi bentuk terlarut oleh bakteri pelarut fosfat. Hal ini terjadi karena bakteri tersebut menghasilkan enzim fosfatase. Enzim fosfatase merupakan sekelompok enzim yang mengkatalisis reaksi mineralisasi hidrolitik secara enzimatik dengan pelepasan fosfat tidak terlarut menjadi terlarut (Ranjan et al., 2013). Perubahan kekeruhan medium di sekitar koloni menjadi bening, karena tejadinya penurunan $\mathrm{pH}$ pada medium (Paul \& Sinha, 2016).

\section{Kemampuan Isolat Bakteri Pelarut Fosfat Secara Kuantitatif}

Hasil uji kuantitaf menunjukkan bahwa, 18 isolat yang menghasilkan zona bening pada uji kualitatif, tidak semuanya mampu melarutkan fosfat. Grafik pelarutan fosfat oleh bakteri pelarut fosfat secara kuantitatif dibawah menunjukkan bahwa, kemampuan isolat bakteri dalam melarutkan fosfat tidak selalu dilihat berdasarkan lebar dari zona bening dan hasil yang ditunjukkan pada uji kualitatif belum cukup efektif dalam menentukan bakteri tersebut mampu melarutkan fosfat.

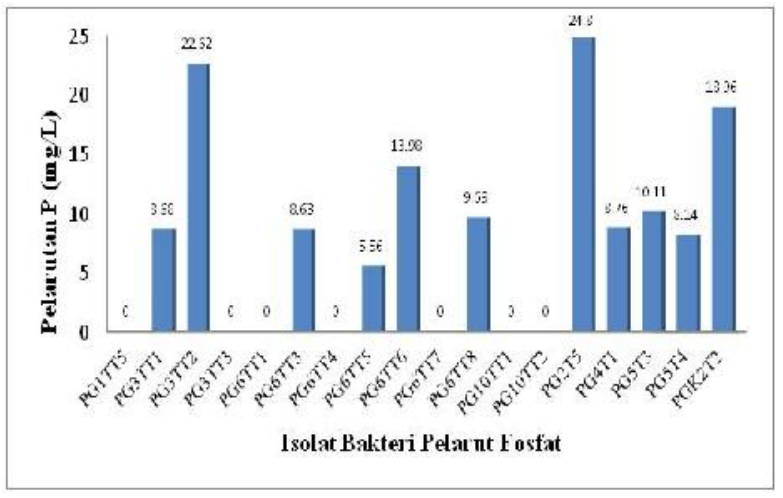

Gambar 2. Grafik Pelarutan fosfat oleh bakteri pelarut fosfat secara kuantitatif

Silaen (2015) mengemukakan bahwa, zona bening pada media padat tidak dapat menunjukkan kemampuan setiap bakteri untuk melarutkan jumlah fosfat terlarut, karena zona bening yang terbentuk merupakan pertanda awal ada atau tidaknya pelarutan fosfat oleh bakteri. Selvi et al. (2017) menambahkan bakwa setiap bakteri pelarut fosfat yang diuji secara kualitatif dan kuantitatif menunjukkan kemampuan dalam meningkatkan kelarutan $\mathrm{P}$ pada media Pikovskaya cair juga berbeda. Berdasarkan uji kuantitatif, terpilih 2 isolat potensial dalam melarutkan fosfat tertinggi yaitu, isolat PG2T.2 dan PG3TT.2 yang masing-masing mampu melarutkan fosfat pada $\mathrm{Ca} 3(\mathrm{PO} 4) 2$ berturut-turut sebesar $24,808 \mathrm{mg} / \mathrm{L}$ dan 22,622 $\mathrm{mg} / \mathrm{L}$.

\section{Identifiksi Bakteri Pelarut Fosfat}

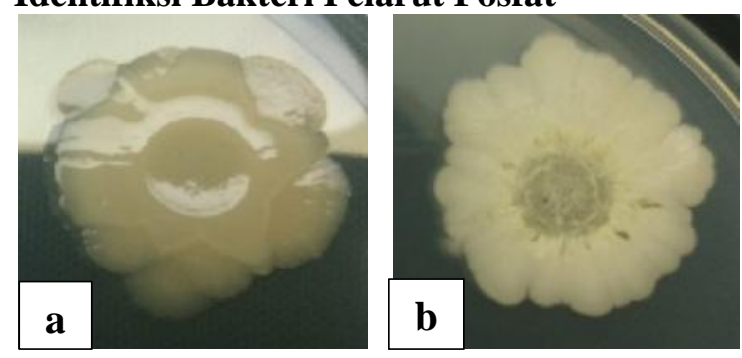

Gambar 3. Bentuk morfologi makroskopis isolat bakteri pelarut fosfat terpilih: (a) Isolat PG2T.5; (b) Isolat PG3TT.2 
Isolat PG2T.5 memiliki bentuk koloni bulat, permukaan koloni timbul, tepi koloni berombak, dan koloni berwarna kuning kecoklatan. Isolat PG3TT.2 memiliki bentuk koloni bulat, permukan koloni rata, tepi koloni berombak, dan koloni berwarna putih kekuningan.
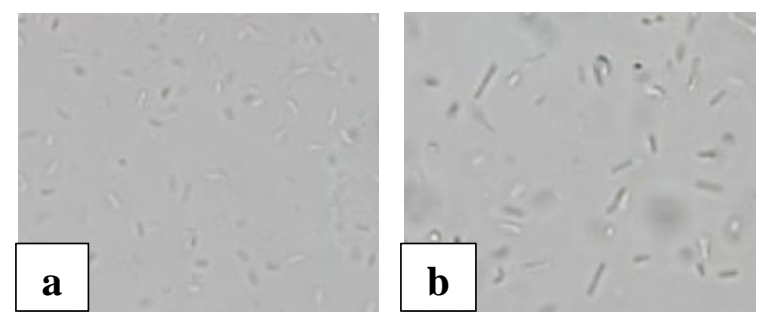

Gambar 4. Bentuk morfologi mikroskopis isolat bakteri pelarut fosfat : (a) Isolat PG2T.5; (b) Isolat PG3TT.2

Hasil pengamatan mikroskopik yanig diamati di bawah mikroskop Olympus DP2-BSW dengan perbesaran 1000x, solat PG2T.5 dan PG3TT.2 memiliki sel berbentuk batang dan bersifat motil. Isolat bakteri PG2T.5 memiliki panjang sel sebesar 3,42 $\mu \mathrm{m}$ sementara isolat bakteri PG3TT.2 memiliki panjang sel sebesar $4,58 \mu \mathrm{m}$.

Identifikasi menggunakan Sistem Biolog dilakukan berdasarkan kemampuan metabolisme sel bakteri terhadap seluruh uji biokimia yang berada di dalam microplate Biolog (berisi 96 well), yang kemudian dicocokkan dengan database.

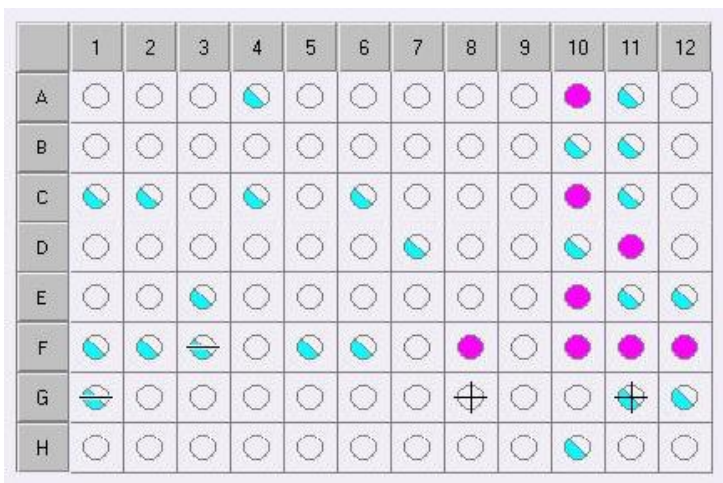

Gambar 5. Hasil pembacaan uji biokimia isolat PG2T.5

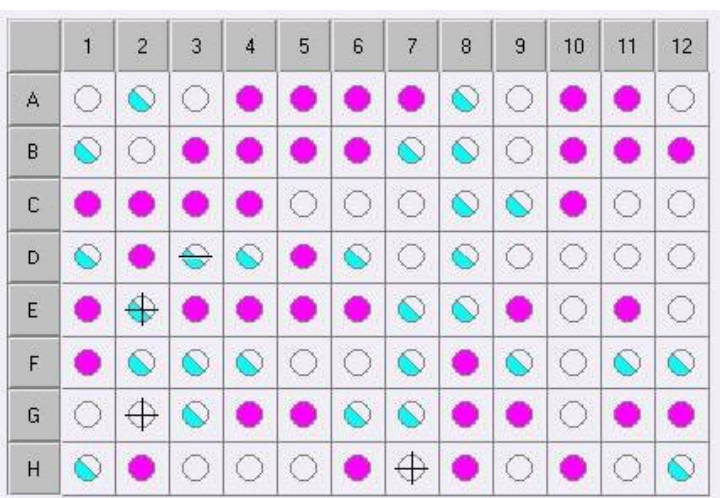

Gambar 6. Hasil pembacaan uji biokimia isolat PG3TT.2

Keterangan : Microplate hasil uji Biolog, terdapat 96 well. • = positif, $=$ negatif, $\quad=50 \%$ positif, $\leqslant=$ tidak sesuai dengan database (seharusnya positif), $\hat{z}=$ tidak sesuai dengan database (seharusnya negatif), $+=$ tidak sesuai dengan database (seharusnya positif).

Berdasarkan hasil pembacaan uji biokimia pada Biolog MicroStation Reader yang telah dicocokkan dengan database, didapatkan sejumlah karakteristik dari isolat PG2T.5 dan PG3TT.2 dengan mengamati reaksinya terhadap $\mathrm{pH}$, tingkat salinitas, toleransi terhadap asam laktat, ketahanan terhadap senyawa kimia termasuk antibiotik, kemampuan mereduksi, produksi asam amino, sumber karbon dan lainnya. 
Tabel 2. Karakteristik fisiologis isolat PG2T.5

\begin{tabular}{|c|c|}
\hline Parameter & Karakteristik \\
\hline $\begin{array}{l}\text { Gram } \\
\mathrm{pH} \\
\text { Salinitas }(\mathrm{NaCl}) \\
\text { Toleransi terhadap asam laktat }\end{array}$ & $\begin{array}{l}\text { Positif, } \\
6 \\
1 \%-8 \% \\
1 \% \text { sodium lactate }\end{array}$ \\
\hline $\begin{array}{l}\text { Ketahanan terhadap senyawa } \\
\text { kimia (termasul antibiotic) }\end{array}$ & 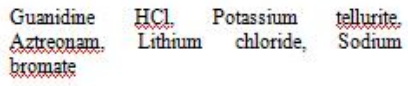 \\
\hline Kemampuan mereduksi & Tetrazolium violet, Tetrazolium blue \\
\hline Produksi asam amino & $\begin{array}{l}\text { Gelatim, L-alanine, L-arginine, L-aspartic acid, } \\
\text { L-glutamic acid, L-histidine, L-pyroglutamic } \\
\text { acid, L-serine }\end{array}$ \\
\hline $\begin{array}{l}\text { Produksi Sumber karbon } \\
\text { - Gula }\end{array}$ & 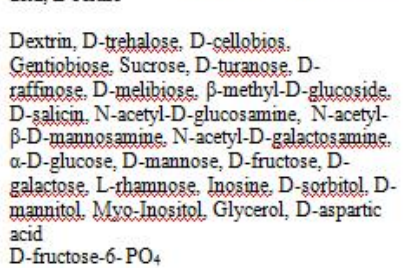 \\
\hline $\begin{array}{l}\text { - Hexose acid } \\
\text { - Carboxylic acids, esters, dan } \\
\text { fatty acids }\end{array}$ & $\begin{array}{l}\text { Pectin, D-galacturonic acid, L-galactonic acid } \\
\text { lactone, D-gluconic acid, Munic acid, Quinic } \\
\text { acid, D-saccharic, acid } \\
\text { D-lactic acid methyl ester, L-lactic acid, Citric } \\
\text { acid, a-keto-glutaric acid, D-malic acid, L- } \\
\text { malic acid, Bromo-succinic acid, Tween } 40, \gamma- \\
\text { amino butryric acid, Aceto acetic acid, Acetic } \\
\text { acid }\end{array}$ \\
\hline
\end{tabular}

Berdasarkan hasil uji biokimia pada sistem Biolog dengan mengetahui karakeristik fisiologis isolat PG2T.5 pada tabel di atas, isolat PG2T.5 muncul sebagai spesies Pseudomonas tolaasii dengan nilai similarity sebesar 0,689 dan dikategorikan sebagai bakteri gram negatif (Tabel 3). Hasil penelitian Viruel et al. (2011) menunjukkan bahwa, isolat Pseudomonas tolaasii, Enterobacter aerogenes, dan Serratia marcencens adalah spesies yang mampu melarutkan fosfat dalam jumlah yang besar pada media Pikovskaya cair di bandingkan dengan isolat lainnya.

Tabel 3. Data biolog isolat PG2T.5

\begin{tabular}{|c|c|c|c|c|c|}
\hline \multicolumn{6}{|c|}{ STerifs I) Psaunnmnnas Irda=i } \\
\hline & FroB & डाM & $D \leqq T$ & Jrganisn Tyzz & Species \\
\hline- & 0.689 & 0.689 & 1./6E & 3iN-VErk & Pseudoranas tolaasii \\
\hline 2 & 0.180 & $0.18]$ & 4.62E & ZN-VErt & Pseudoronas fra] \\
\hline 3 & 0.170 & 0.173 & 4.682 & ÂR-VErt & Pseudoronas fluoleszens \\
\hline 1 & 0.108 & 0.103 & 507 & AN-VErk & Burcholfaia anbfaria \\
\hline
\end{tabular}

Keterangan : $\mathrm{PROB}=$ probability; $\mathrm{SIM}=$ similarity; DIST $=$ distance; GN-NEnt = gram negatif non enteribacteria
Tabel 4. Karakteristik fisiologis isolat PG3TT.2

\begin{tabular}{|c|c|}
\hline Pararrctcr & Kayalstcriztil: \\
\hline Gram & Positif? \\
\hline $\mathrm{pH}$ & \\
\hline Sa mutas $(\mathrm{N}=\mathrm{CN})$ & $1 \% \cdot .8 \%$ \\
\hline Iolerarsi terha dap asax. lakta; & $1 \%$ scdium lac:ate \\
\hline 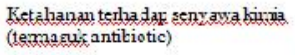 & 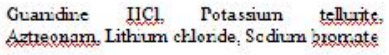 \\
\hline Kemannuaz meredukss & Letrazolum volat, letrazohum blue \\
\hline Frockuksi asentt atrinc & 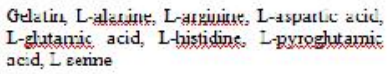 \\
\hline \multirow[t]{2}{*}{ 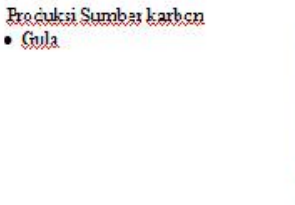 } & 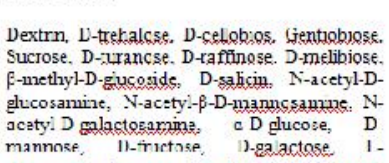 \\
\hline & $\begin{array}{l}\text { ramamnose. Inosune. D-sorbtol. D-manrato. } \\
\text { Myo--nositol. Glycerol. D-aspantic acid }\end{array}$ \\
\hline - Hexose-PO ${ }_{4}$ 's & D-fructuse-6- $\mathrm{FO}_{4}$ \\
\hline - Hexore acic & $\begin{array}{l}\text { Pestir, D-galastugonic, acic, I-galactoris, acid } \\
\text { lactone. D-gliccric acil, Munic acid, Ouiniz } \\
\text { ac:d, D-sacchatic acid }\end{array}$ \\
\hline $\begin{array}{l}\text { - Carboxylic acids, esters, dan } \\
\text { fa:ty acids }\end{array}$ & 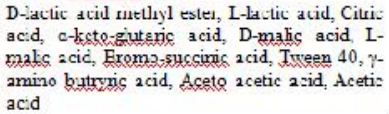 \\
\hline
\end{tabular}

Berdasarkan karateristik fisiologis isolat PG3TT.2 pada tabel di atas, dapat diketahui bahwa, isolat PG3TT.2 adalah spesies Bacillus pumilus dengan similarity sebesar 0,749 dan dikategorikan sebagai bakteri gram positif (Tabel 5).

Tabel 5. Data biolog isolat PG3TT.2

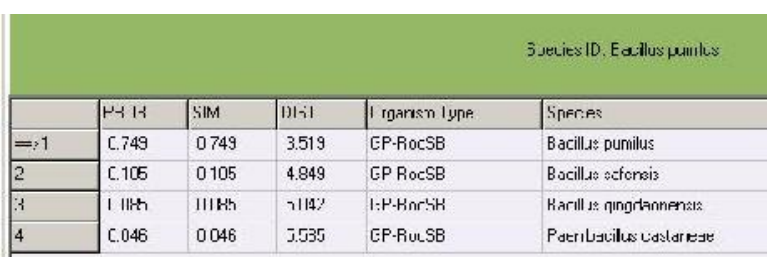

Keterangan : $\mathrm{PROB}=$ probability; $\mathrm{SIM}=$ similarity; DIST $=$ distance; GP-RodSB $=$ gram positif rod shape bacteria

Hasil data yang ditunjukkan oleh alat Biolog kemudian disesuaikan dengan karakteristik makroskopis dan mikroskopis koloni bakteri. Sesuai dengan yang dijelaskan Holt et al. (1994) dalam buku Bergey's Manual of Determinative Bacteriology Ninth Edition bahwa, Genus Pseudomonas memiliki sel berbentuk batang, bakteri gram negatif, motil, dan berukuran 0,5-1,0 $\mathrm{x} \quad 1,5-5,0 \mu \mathrm{m}$. Genus Bacillus memiliki sel berbentuk batang, bakteri gram positif, motil, dan berukuran 0,5-2,5 x 1,2-10 $\mu \mathrm{m}$. Hal ini di dukung 
oleh penelitian yang dilakukan oleh $\mathrm{Mu}$ et al. (2015) bahwa, spesies bakteri Pseudomonas tolaasii memiliki ciri-ciri koloni yang berbentuk bulat, berwarna kuning hingga kecoklatan, memiliki bentuk sel batang dan merupakan bakteri gram negatif. Kusmiatun et al. (2015) dalam penelitiannya menyatakan bahwa, Bacillus pumilus merupakan bakteri gram positif yang memiliki bentuk koloni bulat, berwarna putih hingga putih kekuningan dan memiliki bentuk sel batang. Hal ini serupa dengan hasil pengamatan makroskopis dan mikroskopis yang dilakukan pada isolat PG2T.5 dan PG3TT.2. Genus Pseudomonas sp. dan Bacillus sp. memiliki kemampuan yang paling besar dalam melarutkan fosfat yang tidak larut menjadi bentuk yang larut dalam tanah (Girish et al., 2010)

\section{KESIMPULAN}

Delapan belas isolat bakteri pelarut fosfat berhasil diperoleh dari tanah gambut, dua isolat diantaranya potensial dalam melarutkan fosfat, menurut sistem Biolog kedua isolat tersebut teridentifikasi sebagai Pseudomonas tolaasii (Isolat PG2T.5) dan Bacillus pumilus (Isolat PG3TT.2), masing-masing memiliki kadar fosfat terlarut berturut-turut sebesar $24,81 \mathrm{mg} / \mathrm{L}$ dan $22,62 \mathrm{mg}$ /

\section{DAFTAR PUSTAKA}

Alfiah, L. N., Zul, D. \& Nelvia. 2016. Pengaruh Inokulasi Campuran Isolat Bakteri Pelarut Fosfat Indigenus Riau terhadap Pertumbuhan dan Produksi Tanaman Kedelai (Glycine max L. Merr). Jurnal Agroteknologi 7(1): 7-14.

Biolog. 2011. Biolog: Microbial Identification State of the Science Performance with Unmacthed Power and Versability. USA: Biolog Inc.

Girish, K., Shrikant, B., Sunil, M. 2010. Exploring the Potential of Pseudomonas Species as Phospate Solubilizer, Plant Growth Promoter, Biocontrol Agent and Pesticide Degrader. Asian J Exp Biol SCI SPL 4(2): 4044.

Handayanto, E. \& Hairiah, K. 2007. Biologi Tanah "Landasan Pengelolaan Tanah Sehat". Yogyakarta: Pustaka Adipura.

Holt, J.G., Krieg, N.R., Sneath, P.H., Staley, J.T., Williams, S.T. 1994. Bergey's Manual of
Determinative Bacteriology Ninth Edition. Baltimore: Williams \& Wilkins.

Kusmiatun, A., Rusmana, I. \& Budiarti, S. 2015. Characterization of Bacteruophage Specific to Bacillus pumilus from Ciapus River in Bogor, West Java, Indonesia. Hayati Journal of Biosciences 22(1): 27-33.

Mu, L.-L., Yun,Y. B., Park, S. J., Cha, J. S., Kim, Y. K 2015. Various Pathogenic Pseudomonas Strains that Cause Brown Blotch Disease in Cultivated Mushrooms. Journal Applied Biological Chemistry 58(4): 349-54.

Paul, D. \& Sinha, S. N. 2016. Isolation and characterization of phospate solubilizing bacterium Pseudomonas aeruginosa KUPSB12 with antibacterial potential from river Gangga, India. Annals of Agrarian Science. Hal 1-7.

Ranjan, A., Mahalakshmi, M. R. \& Sridevi, M. 2013. Isolation and Characterization of Phosphate-Solubilizing Bacterial Species from Different Crop Fields of Salem, Tamil Nadu, India. International Journal of Nutrition, Pharmacology, Neurological Disease 3(1): 29-33.

Sagervansh, A., Kumari, P., and, A. N. \& Kumar, A. 2012. Media Optimization for Inorganic Phosphate Solubilizing Bacteria Isolatd from Anand Agriculture Soil. International Journal of Life Science \& Pharma Research 2(3): 245-255.

Selvi, K. B., Paul, J., Vijaya, V. \& Saraswathi, K. 2017. Analyzing the Efficacy of Phosphate Solubilizing Microorganisms by Enrichment Culture Techniques. Biochemistry \& Molecular Biology Journal 1(1): 1-7.

Setiawati, M. R. \& Pranoto, E. 2015. Perbandingan Beberapa Bakteri Pelarut Fosfat Eksogen pada Tanah Andisol sebagai areal Pertanaman Teh Dominan di Indonesia. Jurnal Penelitian Teh dan Kina 8(2): 158164.

Silaen, N. R. 2015. Aktivitas Mikroba Pelarut Fosfat dalam Meningkatkan Kelarutan Fosfat Alam dan Memperbaiki Pertumbuhan Sorgum Manis. Skripsi. Institut Pertanian Bogor, Bogor. 
Viruel, E., Lucca, M.E. \& Sineris, F. 2011. Plant Growth Promotion Traits of Phosphobacteria Isolated from Puna, Argentina. Arch Microbiol 191: 489-96.

Situmorang, E. C., Prameswara, A. S. H. C., Mathius, N. T. \& Liwan, T. 2015. Indigenous Phospate Solubilizing Bacteria from Peat Soil for an Eco-friendly Biofertilizer in Oil Palm Plantation. Renewable Energy and Energy Conversion Conference and Exhibition Vol 1: 65-72. 